\title{
Early ethnographic work at the Hermannsburg Mission in Central Australia, 1877-1910
}

\author{
Anna Kenny
}

The early ethnographic work by the German Lutheran missionaries A. H. Kempe (1844-1928), L. G. Schulze (1851-1924) and Carl Strehlow (1871-1922) at the Hermannsburg Mission among the Aranda in Central Australia is not well known. Kempe and Schulze, for instance, are better known for their reporting of killings of Aboriginal people, their efforts to stop frontier violence and for their epic journey from Bethany in South Australia to the unforgiving centre of Australia that lasted nearly 18 months. Their journey has been immortalised in a booklet called Venture of Faith (Scherer 1963), which describes the missionaries' route of 900 kilometres through waterless desert stretches with an entourage of 37 horses, 20 cattle and nearly 2,000 sheep in the 1870s (Kenny 2013: 15). Immediately after their arrival at Hermannsburg, while they were still building houses for themselves and pens for their livestock, they began their study of Aranda, which Carl Strehlow would continue into the early 1920 s.

\footnotetext{
1 A postdoctoral fellowship at The Australian National University that is part of an Australian Research Council Linkage grant (LP110200803) has made it possible to write this chapter.
} 
GERMAN ETHNOGRAPHY IN AUSTRALIA

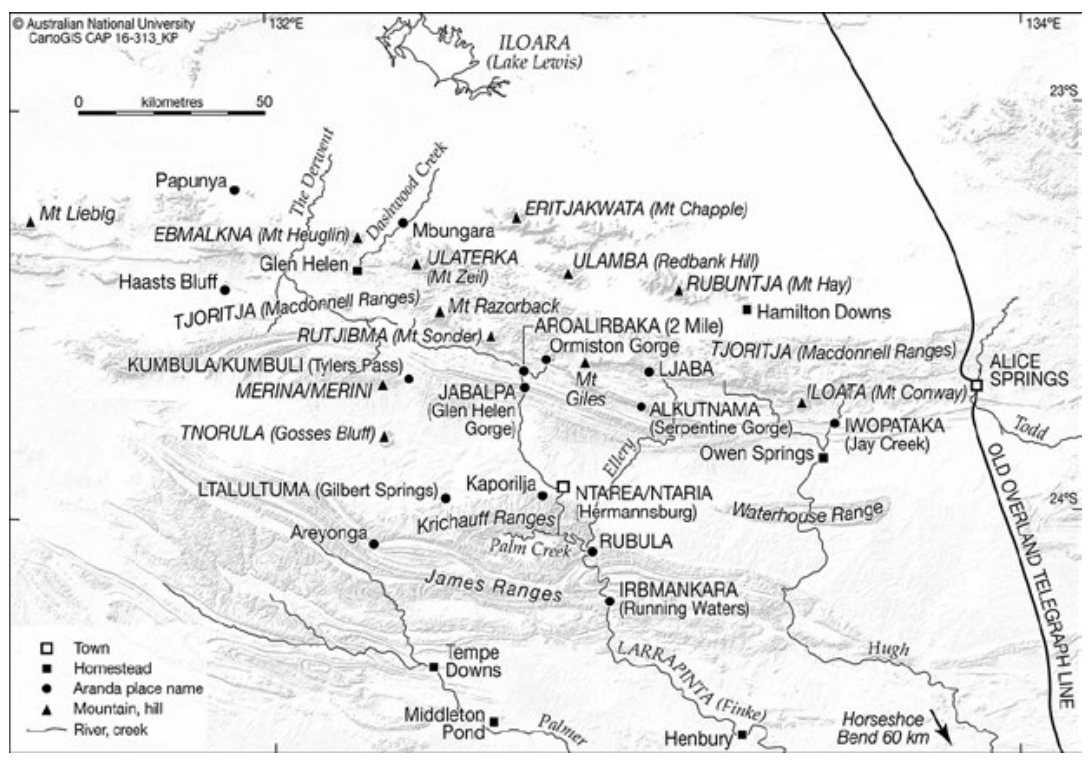

Map 7.1 Aranda names with their European equivalents for the area west of Alice Springs.

Source: CartoGIS, The Australian National University.

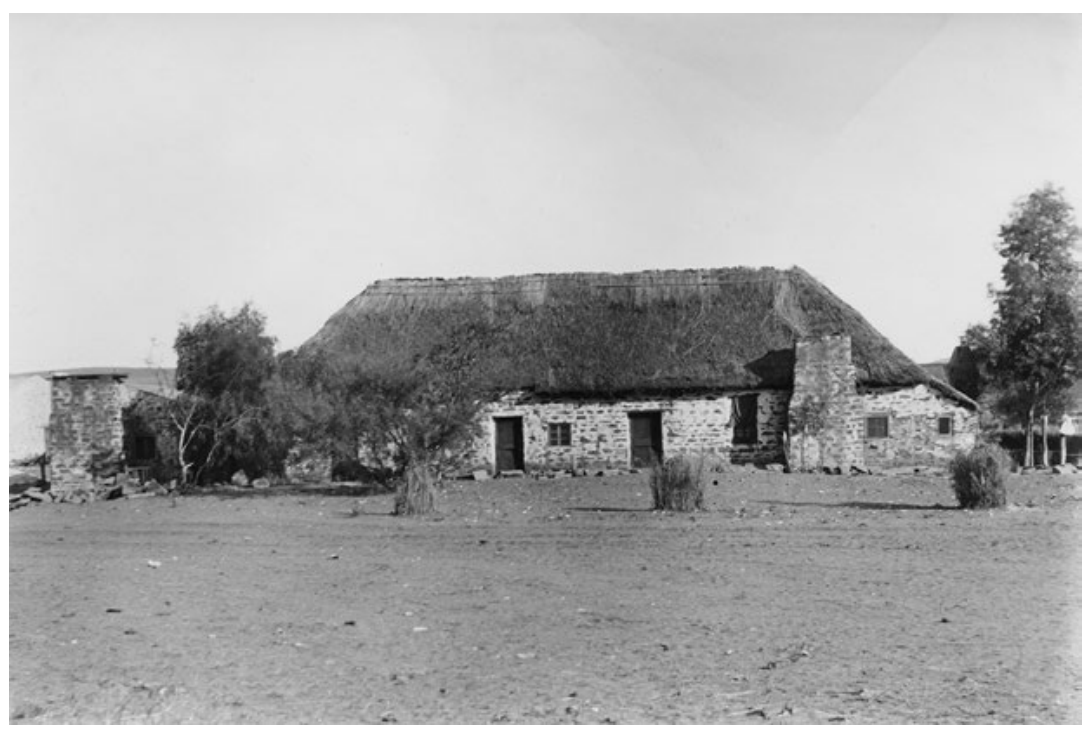

Plate 7.1 Hermannsburg, 1895.

Source: SRC 05846, Strehlow Research Centre, Alice Springs. 
The training they received assumed that they would learn the language of the people whom they were sent to serve. It was a crucial part of Luther's reformation that the word of God was to be taught in the vernacular and translated into a people's mother tongue (Moore 2015: 39; Wendt 2001: 8). At the mission seminary in Hermannsburg, Germany, for example, they even used the Bible in Plattdeutsch (the German vernacular of that region). As a consequence, it was characteristic of nineteenthcentury German Protestant mission theology and practice to pay special attention to a people's language and its implications for idiom and other dimensions of culture (Schild 2004: 54).

The site on the upper Finke River the missionaries chose for the mission is known as Ntaria and is associated with the ratapa ('twin') dreaming. ${ }^{2}$ They named the mission Hermannsburg after the seminary in which they had trained and tentatively called the Aboriginal people 'Aldolinga', meaning 'from the west'.

Today, the local people call themselves Western Aranda or Tjoritjarinja, meaning 'belonging to the Western MacDonnell Ranges' (Kenny 2013: 17). These Arandic people used to be hunters and gatherers; now they live in scattered small remote communities. They still speak their own language, hold their own beliefs glossed in English with the terms 'The Dreaming' or 'The Law' and perceive their surroundings as a 'totemic landscape'. Their society is structured by a classificatory kinship system and their landownership system is essentially traditional with some adaptations resulting from settlement. At the same time, there is a strong Lutheran imprint on their society (Austin-Broos 2010).

According to Schulze (1891), Central Australia was very sparsely populated when they set up the mission, and during their residence they could see that the local people were 'considerably' reduced due to internal feuding, low birth rates, shootings by Europeans and smallpox, which seems to have arrived in the area just before Europeans. Progress in spreading the Gospel was slow and life on the frontier incredibly harsh. By 1891, the mission was abandoned and the missionaries had succumbed to the hardship and challenges of the desert. However, three years later, Carl Strehlow arrived to re-establish the mission, in 1894.

2 See Carl Strehlow (1907-20: Vol. I, pp. 80-1; Vol. II, p. 72, fn. 3; Vol. III, part 2, pp. 122-4) and T. G. H. Strehlow (1971: 758). 


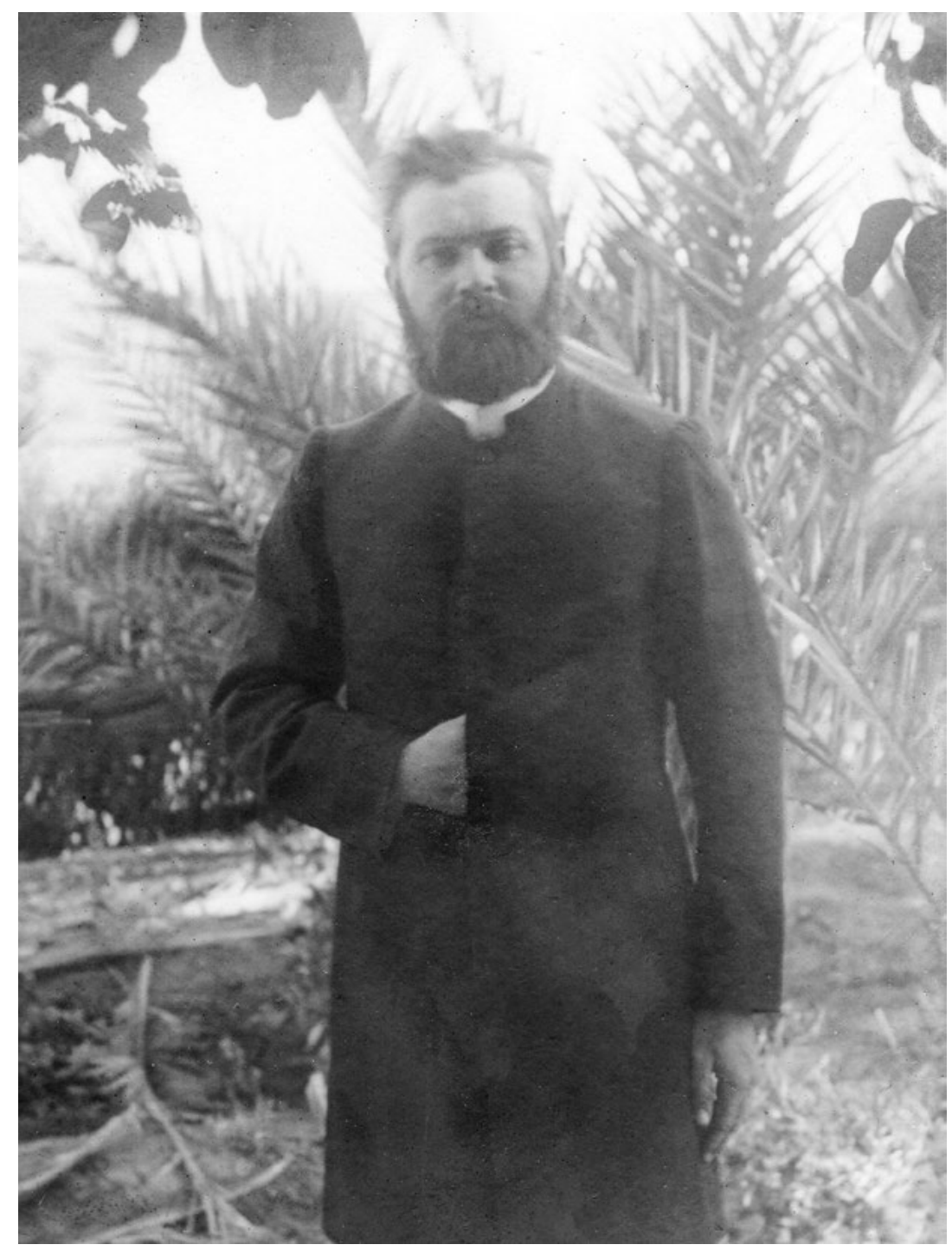

Plate 7.2 Carl Strehlow in his garden, 1901.

Source: SRC 07760, Strehlow Research Centre, Alice Springs.

In the course of learning Aranda, these missionaries collected and published not only linguistic, but also ethnographic data. Thus, the documentation of Aranda culture began at first contact in 1877. 


\section{Early Arandic ethnography}

By 1880, the missionaries' language work had progressed well and they had produced a school primer and a book of Bible stories, psalms, hymns and prayers in the local language. Also, their studies of the local customs and practices had made some headway.

In 1882, Kempe published a paper on the plants of the Finke River in Central Australia in which he describes some of their local uses. One year later, in 1883, he published the first, very short ethnographic account about the people they had met at Ntaria called 'Zur Sittenkunde der Centralaustralischen Schwarzen' ('About customs of Central Australian blacks') (Kempe 1883). Although it is only five pages long, marred with common stereotypes of the time and first impressions (Kempe 1883: 52), it contains data that were of interest to anthropological investigation at the time. It covers in a very preliminary manner gesture language, sections, totems and altjira. Other than this short piece, he published only texts for mission purposes and 'A grammar and vocabulary of the language spoken by the Aborigines of the MacDonnell Ranges' (Kempe 1891a). His vocabulary is noteworthy because it contains nearly 2,000 words; many Australian languages have survived in samples of only 17-100 words in works such as Curr's compilation (1886-87). Kempe's strength was clearly linguistics and not ethnography. ${ }^{3}$

In 1886, based on data collated by Kempe and Schulze, F. E. H. Krichauff published a short paper called 'Customs, religious ceremonies, etc., of the "Aldolinga" or "Mbenderinga" tribe of Aborigines of the Krichauff Ranges, South Australia'. He extracted data from papers and letters Kempe and Schulze had sent to their superintendent, G. A. Heidenreich. Krichauff mentioned 'religion', 'festivals' in which emus and other species were worshiped, ceremonies, myths relating to the ancestral being Malbanca and how ancestors originated from primordial beings, beliefs about celestial bodies, erinja ('evil spirits'), mortuary rites and 'Altegiva' (a misspelling of Altjira) (Krichauff 1886: 35-6). Krichauff's paper has to be treated with great care because he conflated and confused concepts and mythical narratives of the original findings of the missionaries.

3 Kempe's language work and his interest in flora and fauna-an acacia, Acacia kempeana, was named after him—-were what made a lasting contribution to the knowledge of Australia's centre. 
During the 1880s, both Kempe and Schulze corresponded with A. W. Howitt on aspects of Aboriginal culture. Schulze's letters included data about 'marriage rules' and, in particular, the 'eight-class' system, ${ }^{4}$ which was a 'new discovery'. At the end of a letter written on 16 November 1887, he let Howitt casually know: 'P.S. Our tribe divides in more than 4 classes, as soon as possible I shall write it.' ${ }^{5}$ While Howitt did not use Schulze's materials in his classic The Native Tribes of South-East Australia, he used information obtained from Kempe about the gesture language of the 'Aldolinga' (Howitt 1904: 727-35).

Schulze wrote in 1891 the first substantial ethnographic piece on the Aranda, called 'The Aborigines of the upper and middle Finke River: Their habits and customs' (Schulze 1891). His work shows that he was an apt ethnographer and had a flair for social observations. Although he makes some derogatory remarks about Aboriginal people (Schulze 1891: 219, 221), he does not descend to evolutionary sequencing. After describing the harsh nature of the Aranda's country — which he thought was 'at some places most striking and picturesque' (Schulze 1891: 211)-he briefly described the flora and fauna (pp. 214-17) and listed animals that were of particular importance to the Indigenous population. He collected, for example, Aboriginal names of nine different lizards, 22 different snakes and nine different fish. Among other topics, he discussed social organisation-in particular, the subsection system (Schulze 1891: 223-7) — mother's place (pp. 238-9), altjira, customs relating to death, Itana ('ghost'), guruna ('soul'), art forms, bush medicines, shelter, ceremonies and increase rites; he even recorded a tjurunga song (pp. 243-4).

Both Schulze and Kempe witnessed ceremonies (Schulze 1891: 221, 242-4). They were present at 'festivals or dances' called by the Aranda tjurunga and ildada, which:

are ordered and arranged by the old people. Each one of these has one or more of these tjurunga as his special privilege or monopoly. This right does not pass to his sons as an inheritance. (Schulze 1891: 242)

These ceremonies-such as 'the ilia tjurunga, or emu festival', 'the jarimba tjurunga, or fish tjurunga, \&c' (Schulze 1891: 242)—related to the earthbound mythical beings and became one of the central interests

4 Five letters by Reverend L. Schulze to A. W. Howitt, 1887-89, Howitt Papers, MF 459, Box 1051/Icc, State Library of Victoria, Melbourne.

5 L. Schulze to A. W. Howitt, 16 November 1887, Howitt Papers. 
of Australian ethnographers (Spencer and Gillen 1899, 1904; Strehlow 1907-20: Vol. III, part 1, Vol. IV, part 1; Strehlow 1947, 1971). Schulze observed that they were not 'mere pleasure-bouts', but had 'a religious significance', and he wrote:

If one attempts to deprecate the tjurunga of the old, it may happen one day that the traducer is killed for this offence, a case of the kind having occurred in the MacDonnell Ranges only a few years ago.

These festivals serve as reminders, and extol the past, conjoined with prayers that these animals \&c., may again appear in the same numbers, of similar size, \&c.

When everything is ready, the festival commences towards the evening. Women and children hurry towards the spot, and sit down together in a mass at one end of the arena, the men sitting in front of them. The chief old man and the festive dancers sit apart at a little distance. The singing, conducted by the onlookers, begins. One or two dancers then step forward and execute a dance consisting in keeping time to the singing by vigorous stamping with the feet, endeavouring at the same time to imitate the peculiarities of the particular animals that lends its name to the festival. After a while a pause is made, succeeded by the performance of another, and thus it goes on throughout the whole night, and for three or four nights in succession, while they rest and sleep by day. (Schulze 1891: 243)

Most of the words of these songs are partly obsolete, and partly taken from other dialects. This explains why they are not understood by every one. One knows one song, another a different one, all being connected with the particular tjurunga, and derived from their ancestors. Their festivals of circumcision have not been seen by us. What I know of it is only by hear-say, hence I merely mention it. Their youths are circumcised at puberty. (p. 244)

Baldwin Spencer's, Frank Gillen's and Carl Strehlow's data about ceremonies suggest that the events Kempe and Schulze had witnessed were certainly not just entertainment, but were rites that were commonly performed at important places in Central Australia and also at public sessions of male initiation. Carl Strehlow (1907-20) made extensive records of both tjurunga and ltata (Schulze's ildada) ceremonies that can be stand-alone ceremonies or part of the initiation process, which, according to Strehlow, had seven stages at the turn of the twentieth century. The last stage was the inkura (Spencer and Gillen's engwura) ceremony; it was the largest and most prestigious ceremonial gathering and drew people together from far-flung places to witness the conclusion of the rites that brought young men into adulthood. All types of ceremonies and performances 
had either the purpose of intitjiuma (Luritja equivalent: tintinpungañi), meaning 'to initiate into something, to show how something is done', or the purpose of mbatjalkatiuma (Luritja equivalent: kutintjingañi), meaning 'to bring about, make fertile, improve the conditions of' (Strehlow 1907-20: Vol. III, part 1, pp. 1-2), and had public aspects that were witnessed by women, children and the uninitiated. At many stages of initiation women played a role, performing, for instance, dances called ntaperama (Strehlow 1907-20: Vol. IV, part 1, p. 19) and smoking ceremonies called ulbuntakalama (p. 36). The general public was usually never far from the privileged procedures, offering practical, ceremonial and emotional support.

Following in the footsteps of his predecessors, Carl Strehlow started his linguistic as well as his ethnographic investigations on arrival in Hermannsburg in 1894, drawing on Kempe's and Schulze's work. His previous experience at Bethesda (Killalpaninna) with the Dieri (Diyari) ${ }^{6}$ people and his knowledge of their language and their joint work on the Bible translation are likely to have helped him quickly grasp the intellectual concepts of the Aranda and Luritja at Ntaria.

Carl Strehlow had been educated at the Neuendettelsau seminary in southern Germany, which trained its graduates rigorously. The classical orientation of the Neuendettelsau curriculum gave its students a solid basis from which to recognise structures of foreign languages, and assisted the writing of grammars and dictionaries-essential for the translation of the Scripture, mission preaching and schooling. In addition to classical languages, correct German style and essay and speech writing were taught, along with English. Other subjects that were prominent were music, which is deeply embedded in Lutheran tradition, and, under the director Johannes Deinzer, ethics. Neuendettelsau was less conservative and pietistic than other mission training institutions, such as Hermannsburg in northern Germany or the Basler Mission in Switzerland.

Strehlow arrived with an open mind and respect for the cultures of others. He combined all the interests of his predecessors in his work, which took on a cosmographic character covering most aspects of Aboriginal life and resulted in his classic ethnography, Die Aranda- und Loritja-Stämme in Zentral-Australien (The Aranda and Loritja Tribes in Central Australia) (Strehlow 1907-20), published in German, and a large comparative

6 The spelling Dieri is still commonly used by Dieri people today, while Diyari is a modern rendering. 
dictionary with about 7,600 Aranda, German, Luritja and Dieri entries. Unlike the work of Kempe and Schulze, Strehlow's was influenced by views that would shape modern anthropology and were taken forward by his son, T. G. H. Strehlow (see Morton, Chapter 8, Austin-Broos, Chapter 9, and Gibson, Chapter 10, this volume).

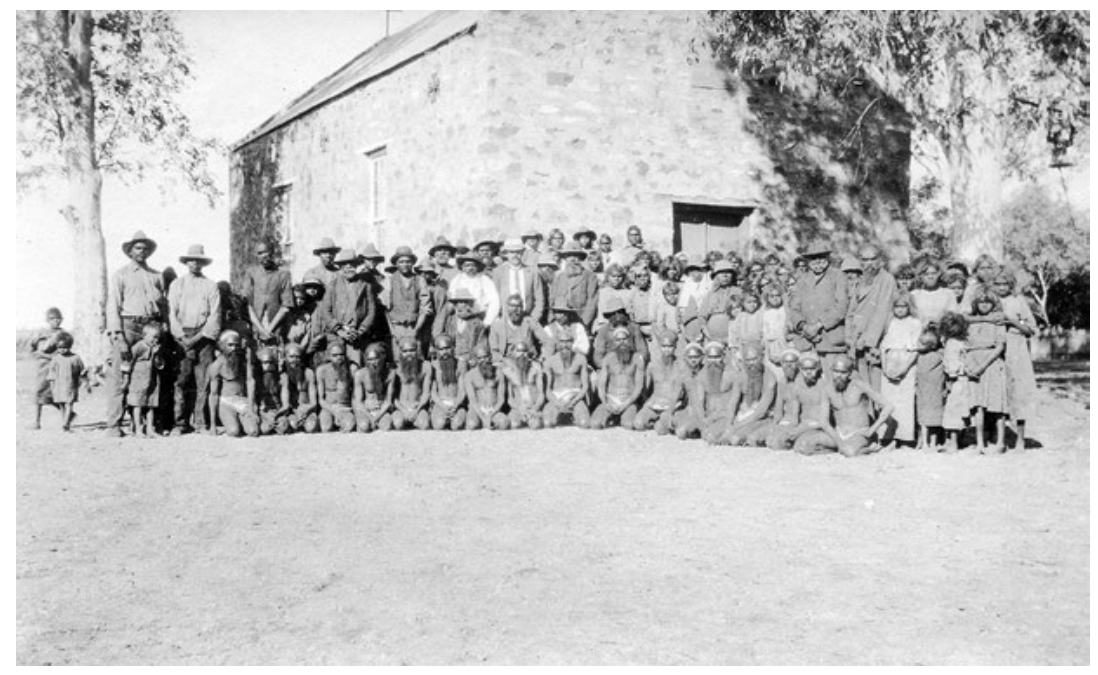

Plate 7.3 Aranda Lutheran people and a group of visiting Luritja people at the Hermannsburg Mission, 1910s.

Source: SRC 06192, Strehlow Research Centre, Alice Springs.

In the following, I discuss briefly three topics - the subsection system, the altjira concept and mother's place-and show how the data of Kempe, Schulze and Strehlow senior not only contributed to the archival record of Central Australian anthropology, but also remain highly relevant today in land and native title claims.

\section{Sections and subsections}

Section systems among Aboriginal Australians had been known since 1855 from Reverend William Ridley's journey through the inland of south-east Queensland (Ridley 1861). Thus, Kempe (1883: 52), reporting on the section system among people at the Hermannsburg Mission in 1883presumably based on information obtained from Southern Aranda people who still had not fully embraced the subsection system (Kenny 2013: 177)—was nothing unusual or new. However, Schulze's first observations 
about the 'eight-class' or subsection system that is found only in northern and Central Australia, were new (Kenny 2013: 169; Koch forthcoming). He mentions the subsection system in letters (1887-89) to A. W. Howitt that show that he was having a hard time understanding how it worked and in obtaining reliable data from his Aranda informants, whom he had to interrogate over and over again ${ }^{7}$ and still could not quite make sense of what they were telling him. On 20 November 1889, for example, he wrote, confused and irritated, to Howitt:

So for example, a Beltara is also Bungata; a Gomara also Mbitjana; a Bunanka also Gnuria; a Burula also Ngala, just with the difference, that one would like to be more Beltara than Bungata, the other would like to be more Bungata than Beltara. ${ }^{8}$

He spent many hours trying to elicit from them how this eight-class system worked, concluding that there used to be eight classes, but, due to demographic loss, only four classes remained. ${ }^{9}$ On 10 December 1889, after further attempts to get to the bottom of the eight-class system, Schulze wrote:

I have queried the natives several times for hours, but have not been able to discover anything too astonishing, which supports my view that a long time ago, they [the Aranda] certainly had 8 classes, in which only two particular classes could marry each other. For example, a Beltara-man may only marry a Gomara woman, a Bungata man may only marry an Mbitjana woman, and so forth. As the population diminished there were for example not enough Gomara women left, so they dropped the older regulation, and permitted Beltara men to also marry Mbitjana women and Bungata men could also marry Gomara women; and vice versa Gomara men may not only marry Beltara but also Bungata women, and Mbitjana men can not only marry Bungata but also Beltara women. Likewise with the other two class pairs. A Bunanka man who usually may only marry Burula, may now also marry a Ngala, if he cannot get a Burula. ${ }^{10}$

In his 1891 paper, Schulze maintained that the only way he had been able to understand this system was to collect as many examples as possible and then discuss them with informants. He remarked that when his

7 L. Schulze to A. W. Howitt, 8 May 1888, Howitt Papers.

8 L. Schulze to A. W. Howitt, 20 November 1889, Howitt Papers.

9 ibid.

10 L. Schulze to A. W. Howitt, 10 December 1889, Howitt Papers. 
informants were asked to explain their social and religious customs, their final reply was always 'Wara', meaning 'Our habit; nothing else' (Schulze 1891: 219). This reasoning added substantially to:

the difficulty of discovering their motives, and caused the investigation of their social regulation in respect of their Eight-class system to be so troublesome. Information can only be obtained by accumulating many examples from their actual life, and then directing their attention to them. (Schulze 1891: 219)

Although Schulze had spent considerable time trying to solve the eightclass puzzle, he got muddled. He had not realised he was in an area where the section and subsection systems converged. The systems were straining to interlock, which was still the case in the 1930s (Strehlow 1947: 72), and he may have had among his informants some Luritja people who claim subsection affiliation through their mother if their parents' marriage had been irregular, in contrast with Aranda, who are always patrilineal in this regard. Finally, it might have been the case that the eight-class system had gone into temporary disuse as broader social networks waxed and waned in Central Australia.

Males.

$\left\{\begin{array}{l}\text { Beltara } \\ \text { Pungata }\end{array}\right.$

Gomara

Mbutjana

Sunanka

Knuraia

SPurula

Noala
Females.

Gomara

Mbutjana

Beltara

Pungata

Purula

Ngala

Bunanka

Knuraia
Children. Bunanka Knuraia Purula Ngala Beltara Pungata Gomara Mbutjana

Plate 7.4 Schulze's version of the eight-class or subsection system. Source: Schulze (1891: 224).

However, Schulze did get some aspects right, which was an achievement considering his circumstances. He first concluded correctly that, regarding marriage, it is ideally between 'a prescribed pair, thus forming four pairs of classes by prescription, although eight by name' (Schulze 1891: 223), but he did not get all pairs properly matched. Second, he also correctly asserted that 'paternal descent' was always the rule regardless of whether a man had married into the right Arandic subsection group. 
According to Koch, Schulze's claim that, regardless of the subsection of the mother, the child's subsection is always determined by that of its father is inconsistent with his own data. Schulze contradicted his claim by placing the children of a male Bunanka in the Beltara subsection and those of a Knuraia in Pungata, which would be accurate if the subsection of the child had been determined by that of the mother or if, in Schulze's time, the joining of the original four terms and their filiations with the new set of terms was applied-that is, Penangke-Petharre (Schulze's Bunanka-Beltara) continued as a patrifilial pair rather than switching it to Penangke-Pengarte (Schulze's Bunanka-Pungata) beside KngwarrayePeltharre (Schulze's Knuraia-Beltara) (Koch forthcoming). ${ }^{11}$

Contemporary Indigenous views of the system as well as data from Spencer and Gillen $(1899,1927)$ and Carl Strehlow recorded only some years later, by contrast, match the subsections as Kamara-Purula, Ngala-Mbitjana, Paltara-Knuraia and Bangata-Pananka, and have Aranda marriage rules prescribing that Kamara marries Paltara, Purula marries Pananka, Ngala marries Knuraia and Mbitjana marries Bangata. Carl Strehlow (1907-20: Vol. IV, part 1, p. 63) showed the Aranda marriage rules of the eight-class or subsection system (Plate 7.4); A and B are parents and C their children.

Third, Schulze (1891: 224) observed correctly that 'those who stand on the same line marry first, but under certain circumstances marriages in a diagonal line are permitted to take place', which is correct in terms of the section system. He explained second-choice marriage to have come about because the Aranda:

became much reduced in number, one class may have contained only a few men, and the other a few women, they then resorted to the relaxation of the rule to avoid extinction. (Schulze 1891: 224)

11 Koch uses the modern spelling of Central and Eastern Arrernte, a system that is called the IAD or common system. 


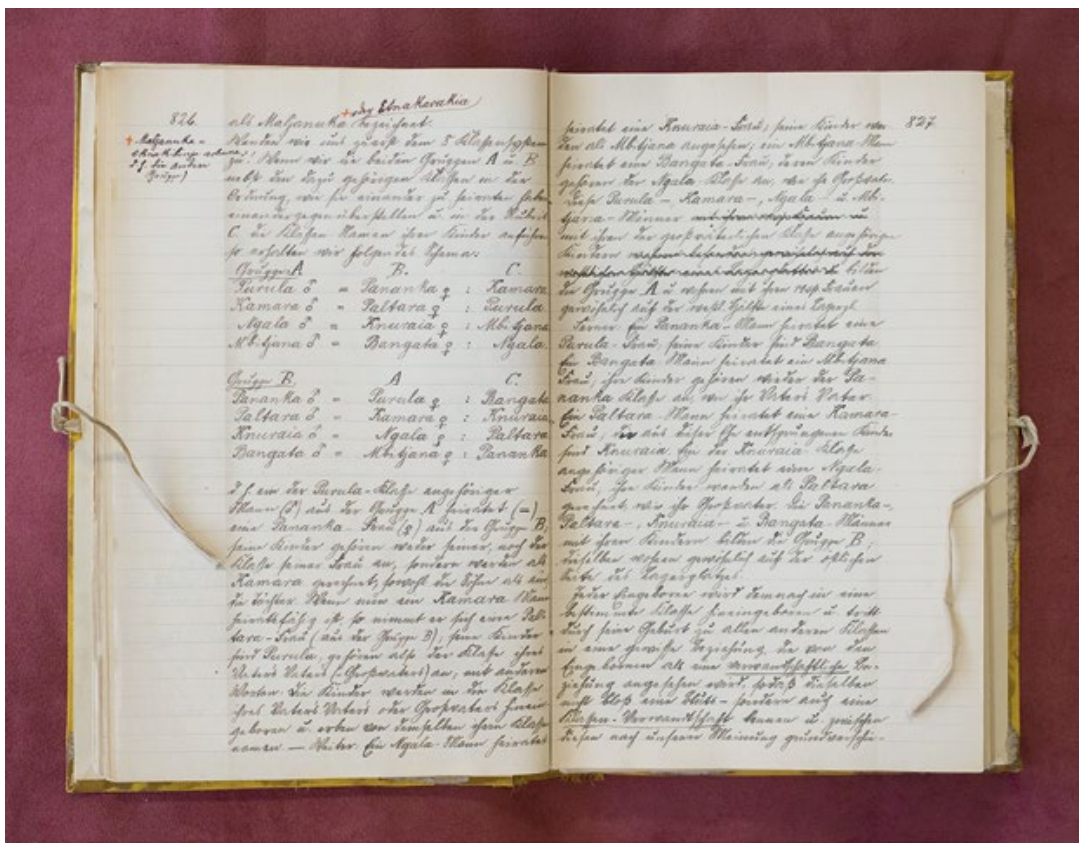

Plate 7.5 Pages 826-7 of Carl Strehlow's manuscript Leben. On page 826, centre, he illustrates how the subsection system of the Aranda works.

Source: Image courtesy of Strehlow Research Centre, Alice Springs.

To illustrate this point, he added that the numbers of the local population had been significantly reduced and marriages could not take place within the prescribed limits, especially as many white people attached 'to themselves native women' (Schulze 1891: 224).

Subsequent researchers amended his views and findings. Carl Strehlow (1907-20: Vol. IV, part 1) elaborated substantially on both the four-class and the eight-class systems, clarifying how they worked and other aspects of Aranda and Luritja social organisation and life. Through Spencer and Gillen (1899, 1927), the Aranda's social classification scheme became a seminal case-in particular, the eight-class system, called the 'subsection system' by Radcliffe-Brown, who named the system's related kinship classification system 'Arandic'.

Spencer and Gillen maintained that the subsection system had only been introduced into the Arandic world of Central Australia in the 1880s. However, Schulze's observations made at Ntaria at precisely that time on Western Aranda territory suggest otherwise, which is supported by Carl Strehlow's reports in the first decade of the twentieth century 
that, in mythology, the subsections were already well in place and their introduction did not seem that recent (Kenny 2013: 176). He wrote: 'This division of the people into different marriage-classes is regarded as being of very ancient origin and is already hinted at in the legends concerning the people of primordial times' (Strehlow 1907-20: Vol. IV, part 1, p. 62).

Strehlow's data on the mythical ancestors called Mangarkunjerkunja and Katukankara might also suggest that the subsection system had fallen into disuse as interactions and social networks had been disrupted, possibly due to events in the 1870s and 1880s, such as the building of the overland telegraph line, diseases such as smallpox, the Barrow Creek massacres or simply due to the unpredictable arid environment in which droughts and demographic losses occurred. He wrote:

He [Mangarkunjerkunja] also gave them a marriage system, which regulated marriage between the classes. According to his instruction the two groups, which had been differentiated and separated at the beginning of time, should marry each other in the following manner:

I. Land dwellers II. Water dwellers

Purula should marry Pananka

Kamara should marry Paltara

Ngala should marry Knuraia

Mbitjana should marry Bangata

and vice versa. Then Mangarkunjerkunja divided the large territory, which the Aranda inhabit today, among the classes. (Strehlow 1907-20: Vol. 1, p. 6)

The marriage system that Mangarkunjerkunja had taught also disintegrated. (p. 8)

The moral decline spread further and further north, until a tnunka [kangaroo rat] man by the name of Katukankara [the immortal father] left Anjatjiringi in the north and once more re-enforced the marriage laws amongst the Aranda that Mangarkunjerkunja had given to them. (p. 8)

According to recent research by Koch on subsections and their spread, the subsection system would have arrived among Kaytetye and Anmatyerr(e) (northern neighbours of the Aranda) at the latest in the first half of the nineteenth century, which would be one generation before the Aranda (Arrernte) had the subsection system (Koch forthcoming). Based on 
Schulze's letters to Howitt in the late 1880s, Carl Strehlow's data collected between 1894 and 1910 and estimates based on phonological change and the principles of adaptation of loan words (Koch forthcoming), it is likely that the subsection system had certainly arrived by the 1870 s among the Western Aranda, if not decades earlier.

\section{'Altjira'}

A concept that becomes well discussed in Arandic ethnography as we pass through the twentieth century is altjira and its significance in Central Australian totemic beliefs and ceremonial life. According to Austin-Broos (2010: 16), altyerre (altjira) and altyerrenge are 'possibly the most contested words in modern Australian ethnography'.

It appears that the first written remark on the concept of altjira, and relating, among other things, to a 'high being', was made by Kempe over 130 years ago, in 1883. Kempe (1883: 53) recorded that '[c]hildren are a gift of Altjira (God)', ${ }^{12}$ but did not make any other comment about what this might mean, and, interestingly, did not include it among the 2,000 words of his published wordlist. In his mission publications, he used the word altjira to denote the Christian God.

Schulze added to Kempe's scrap of information that altjira means 'not made'13 and was connected to mother's place called tmara altjira. He wrote:

They pretend that the tjurunga arknanoa ['festival plates'] were altjirathat is, were not made-but I suspect, as they occasionally give some to white people, that the old men and sorcerers make them themselves.

(Schulze 1891: 242)

Carl Strehlow confirmed that the place called tmara altiva was associated with mother's totem and he added many more details to the written record about a 'supreme being' called altjira, unwittingly antagonising Sir Baldwin Spencer and triggering a debate about a high god among the Aranda and the meaning of this word that continues into the twentyfirst century (see, for instance, Strehlow 1907-20: Vol. I; Vol. II; Vol. III,

12 Original: Die Kinder, sagen sie, schenkt Altjira (Gott).

13 Carl Strehlow to Moritz von Leonhardi, 13 December 1906, SH-SP-7-1. Held at the Strehlow Research Centre, Alice Springs. 
part 1; Spencer and Gillen 1927; Strehlow 1971; Swain 1985; Kolig 1992; Hiatt 1996; Hill 2002; Strehlow 2004; Austin-Broos 2010; Green 2012; Kenny 2013; Moore 2015).

Carl Strehlow found that the term altjira was polysemic and covered an enormous amount of ground depending on the context in which it was used. He provided several meanings of this term and elaborated on them (see Kenny 2013). He maintained explicitly that the word altjira related to the spiritual and physical world of the totemic earthbound beings, but an altjira was also a 'sky being' called 'Tukura' in Luritja and could be interpreted as a 'high god', as it was the specific being of one of the myths he had recorded. Among its many references, altjira meant 'mother's totem' and had a providing and protecting role, 'like a mother feeds and protects her children during the early years of their lives', and appears in dreams to warn them of danger but also to tell friends about a person's wellbeing (Strehlow 1907-20: Vol. II, p. 57). The particular tjurunga associated with a man's mother, he regarded 'as the body of his altjira (mother's totem ancestor), who would accompany him on his lonely journeys' (Strehlow 1907-20: Vol. IV, part 1, p. 25).

While Strehlow's understanding of the term is evident, it is difficult to judge, based on Kempe's and Schulze's brief remarks on the concept of altjira, what they had understood about it. It appears though that they felt ambivalent about their use of altjira. Kempe, for instance, wrote to Spencer in 1910, 20 years after he had abandoned the mission:

As regards the word 'Altjira' in the language of the natives of Central Australia, I beg to tell you that, so far as I know the language, it is not 'God' in that sense in which we use the word-namely, as a personal being — but it has the meaning of old, very old, something that has no origin, mysterious, something that has always been so, also, always. Were Altjira an active being, they would have answered 'Altjirala': the syllable 'la' is always added when a person exercises a will (force) which influences another being or thing. We have adopted the word 'God' because we could find no better and because it comes nearest to the idea of 'eternal'. The people through the usage of a word often use it as a name for a person. This, according to my conviction, is the true meaning of the word Altjira. (Spencer and Gillen 1927: 596) 
It appears that Carl Strehlow also felt some ambivalence or even unease about its use in the Christian context, after he started corresponding with his editor, Moritz von Leonhardi, who wrote to him in 1905 that it rather surprised him to see that he still used altjira for 'Christian God'.

With their initial limited knowledge about Aboriginal cosmology and ontology, Kempe and Schulze, too, soon adopted the word altjira to denote the Christian God in their efforts to convey their Lutheran beliefs to the Aranda. Besides altjira, they had been told about laia, a kind of paradise, where the souls of people go to after death and where eternal joy lies (Kempe 1883: 56). Beliefs surrounding death were emphasised in Kempe's and Schulze's writing, because what happened to the soul (guruna) after death was, of course, of great interest to them.

While the information about laia, a type of paradise, and altjira, a being of some kind of higher order, appears to be accurate, how the missionaries interpreted the term was another matter. What they had heard about altjira and laia seemed familiar and, since they were trying to find contact points between themselves and the Aranda, what they had elicited from their Indigenous informants seemed to be related to their own concepts of their God and they decided to use it for their own purposes. Although Carl Strehlow kept on using the term altjira in the mission context, he was well aware of the term's large semantic field, discussing it for years with his editor (between 1901 and 1910). By the time he had realised the word's meaning, it was probably too late to replace the word altjira with another for the Christian God. It is noteworthy that at Killalpaninna the missionaries used the loan word Godaia for their own god (Moore 2015), rather than the word mura, which referenced a higher being among the Dieri people of the Lake Eyre region.

Despite their differences in quality and quantity, these early materials on altjira suggest that sky beings of some kind of 'higher order' are likely to have existed at the time of contact in 1877 alongside equally important totemic earthbound beings called dreamings today. It is clear now that altjira covers a very complex domain and that its semantic field and syntactic range were vast. Another example described by Carl Strehlow is the word tjurunga. He found that it had many very complex meanings depending on its context. Tjurunga could mean songs, stories, dances, paraphernalia or sacred objects-for instance, associated with the 
ancestral beings. ${ }^{14}$ In his unpublished dictionary, heilig ('sacred') is part of its meaning as well as 'change into wood or stone' at the end of creative activities (Strehlow 1907-20: Vol. II, p. 77). Tjurunga today usually means 'sacred object' and is not often spoken about (Breen 2000: 60).

Other than providing evidence of a complex belief system, the materials of these early ethnographers make it possible to study language change and trace the semantic shifts of key words such as altjira, tnankara, inkata or even tjurunga back to the first contact period. The examination of altjira's meaning, for instance, indicates that it has undergone some major semantic changes during the past century. Carl Strehlow, as well as Kempe, had observed a wide semantic field for the term altjira and Strehlow had discovered a synonym of the word: tnankara. Géza Róheim (1971: 211), shortly after Strehlow, also noted that this synonym for altjira, tnankara, 'is not often used', and, in his time, T. G. H. Strehlow (1971: 614) found that altjira was rarely used. Today, the Western Aranda use the term altjira to denote the Christian God and tnankara for concepts relating to Indigenous spiritual beliefs (Kenny 2013). Green (2012: 171) has observed a similar development for the Anmatyerr words altyerr and anengkerr, which used to be synonyms.

\section{Mother's place (tmara altjira)}

At the time of these early writers, the subject of territorial organisation was barely on the horizon in Australia. Indigenous landownership and rights became major subjects of research only in the second half of the twentieth century. Kempe and Schulze did not investigate territorial organisation as such when they arrived in Central Australia, though it seems that it was clear to them that the land they had come to was owned by the Indigenous population. Kempe remarked in 1883 that every group named themselves after a particular place, such as a water source or a waterway, or after the region from which they came (Kempe 1883: 52), while Schulze argued that they followed paternal descent and authority was held by the aged men and medicine-men' (the knirabata and ngankara), but that their rule was usually ineffective, as they did not form a 'nation, nationality, tribe, or tribelets', but the main unit was the family (Schulze 1891: 240-2).

14 See Carl Strehlow (1907, 1908, 1910); T. G. H. Strehlow (1947: 84-6; 1971: 770-1); and Carl Strehlow's letters to Moritz von Leonhardi (1906-09) held at the Strehlow Research Centre in Alice Springs. 
Most importantly, though, Schulze (1891: 238-9) made the first remark on matrifiliation in Aranda country. He recorded the term tmara altjira, meaning 'the place where the mother of a dead person was born'. The deceased were oriented to face towards their mother's place, tmara altjira, to which their ltana ('ghost') hurried after death. Also T. G. H. Strehlow wrote in 1964:

when a man died, he was buried (generally in a sitting position) in such a way that his face was turned towards the conception site of his mother: for that was his pmara altjira, his 'eternal home'. (Strehlow 1978: 39)

In this respect, Schulze had recorded that in 'an after-life, the natives say that the souls of all go to laia', but they were not able to explain to him how to reconcile this view with the information about tmara altjira (Schulze 1891: 244), where the soul is supposed to go after death as well.

About 15 years later, Carl Strehlow recorded further details surrounding the tmara altjira, meaning 'maternal totem place' (Strehlow 1907-20: Vol. IV, part 2, p. 16). He was able to explain why Schulze found his informants' view surrounding this place inconsistent. He was told that after a boy has carried his knocked-out tooth with him for several weeks, he tossed it in the direction of his tmara altjira (Strehlow 1907-20: Vol. I, p. 9) and that, after his death and the completion of his second burial ceremony, he would go to his tmara altjira to collect his tooth, which would show him the way to the Island of the Dead (Laia) (Strehlow 1907-20: Vol. III, part 2, p. 9, fn. 4).

Strehlow, too, mentioned connections to mother's conception dreaming, called in Aranda altjira, which is associated with a totem such as ara ('kangaroo'), ilia ('emu'), jerramba ('honey ant'), and so on. He described the relationship of an individual to the mother's dreaming, also called garra altjira or deba altjira, and to mother's conception site, called 'tmara altjira or more precisely, tmara altjirealtja, i.e. the place of the totem associated with me' (Strehlow 1907-20: Vol. II, p. 57; Vol. III, part 1, p. 2). He mentioned the right question to ascertain the totem place of a person's mother-namely, 'tmara altjira (or altjirealtja) unkwanga ntana?' ('Where is the place of the totem associated with you?') (Strehlow 1907-20: Vol. II, p. 58). 
In 1927, Spencer wrote in a postscript that he and Gillen ${ }^{15}$ had also encountered the tmara altjira in the 1890s. Spencer wrote:

Gillen and myself describe the grave as having a depression facing the Alcheringa camp (the Tmara alchera) of the deceased. The difference between Schulze and us is that the former describes the Tmara as being that of the mother, whilst we describe it as that of the dead person. The important point, however, is the evident significance of the word Altjira, used by Schulze, as implying something associated with past times, and not as the name of any person or individual. He defines the Tmara altjira as the place where the mother was born; Gillen and myself as the place where the 'spirit' lived and entered the mother when she became pregnant, and Strehlow, who in this says that Tmara altjira as meaning 'mother's totem'. (Spencer and Gillen 1927: 591)

The important point here is that all three parties found the tmara altjira to be somehow associated with 'mother', which references matrifilial connections to place and country in the contact era. Together, these early remarks on matrifiliation to country indicate what the land tenure system might have been like. In the second half of the twentieth century, research for claims under the Aboriginal Land Rights (Northern Territory) Act 1976 (Cth) and the Native Title Act 1993 (Cth) provoked considerable academic debate around land tenure issues. This is where the material of Kempe, Schulze, the Strehlows as well as Spencer and Gillen, Róheim or Olive Pink becomes particularly interesting.

In addition, Carl Strehlow observed that sets of siblings with the same mother shared a dreaming and the site associated with it. He had found that one of the larger ceremonial objects was associated with altjira ('totem') and could be inherited from mothers. ${ }^{16}$ This seems to be the first indication in the written record of Central Australia that mother's dreaming and place were collectively held, as all children of one mother had the same altjira, implying rights in the mother's place, and that, possibly at different times, different 'totem' affiliations were more or less important or emphasised. Unfortunately, these thoughts were not

15 Spencer references this section to their Native Tribes of Central Australia (Spencer and Gillen 1899: 497). The relevant passage reads: 'It [the body] is placed in a sitting position with the knees doubled up against the chin, and is thus interred in a round hole in the ground, the earth being piled directly on the body so as to make a low mound with a depression on one side. This is always made on the side which faces the direction of the dead man or woman's camping ground in the Alcheringa, that is the spot which he or she inhabited whilst in spirit form.'

16 Moritz von Leonhardi to Carl Strehlow, 2 June 1907. 
developed any further. Nevertheless, they show that the right questions and concepts were emerging. A passage written on 6 April 1907 by Carl Strehlow to von Leonhardi indicates this clearly:

As the tjurunga ['sacred property or object'] is the symbol of the personal totem, some blacks have told me, that the wonninga ['a ceremonial object'] can be seen as the symbol of the maternal totem or altjira. However, I am not yet certain about this, and will make further inquiries. While the tjurunga of individuals are different (each individual has his own totem ancestor), the wonninga as the symbol of altjira would tie the members of a family together, because they all have the same altjira, but all have different ratapa ancestors. It is hard to tell which of the two totems is older, the personal or the one inherited from one's mother. ${ }^{17}$

Although Kempe, Schulze and Strehlow did not connect the issues of social classification, knowledge and land in an understanding of territorial (local) organisation or land tenure, they recorded data on the different ways in which individual people could be connected with place. These data suggest that traditional ownership was dynamic and involved in change that intensified with the impact of settlement.

\section{Conclusion}

Despite their limitations, Kempe and Schulze laid the linguistic and ethnographic groundwork for the study and, more importantly, to some degree the continued vitality of Aranda language. Carl Strehlow's language work and, in particular, his ethnography Die Aranda-und Loritja-Stämme in Zentral-Australien secured the basis for ongoing value being placed on Western Aranda culture. Their Lutheran language tradition, which was fundamentally based on the Herderian view that language contained the spirit of a people, contributed significantly to the cultural survival of the Western Aranda by explicitly emphasising the importance of language.

While Kempe's and Schulze's work is still part of nineteenth-century ethnography, Carl Strehlow's work in its relation to modern anthropology has a transitional status, as it was influenced by anthropological thought developing in Germany and provided the blueprint for his son's seminal work. Although limited by the available tools (as were his predecessors),

17 Carl Strehlow to Moritz von Leonhardi, n.d. [possibly 6 April 1907], SH-SP-11-1. Held at the Strehlow Research Centre, Alice Springs. 
his approach allowed him to collect material for the emerging discipline of anthropology; the ingredients that are essential for a modern comparative study of societies and their cultures are present in his ethnographic work.

In the second half of the twentieth century, it became possible for Aboriginal people in Australia to claim their traditional lands and native title rights under the Commonwealth's Aboriginal Land Rights (Northern Territory) Act 1976 and Native Title Act 1993. The missionaries' ethnographic work showed the Aranda's cultural continuity and that the Aranda were, without a shadow of a doubt, among the original inhabitants of Central Australia. In this context, Schulze's paper is of particular value, because it is based on observations made during the first contact period and treats a particular people rather than seeking to explain 'origin' or trying to systematise social phenomena. His data on tjurunga ceremonies, altjira, tmara altjira and the subsection system are the earliest evidence for the continuity of these features of Arandic culture. In the context of land rights, native title, mining and royalty agreements, their ethnography is still playing an important role in contemporary Australia.

\section{References}

Altmann, M. 1980. The Silver Miner's Son: The history of Louis Gustav Schulze missionary. Hahndorf, SA: Fox Publishing.

Austin-Broos, D. 2010. Translating Christianity. The Australian Journal of Anthropology 21(1): 14-32. doi.org/10.1111/j.1757-6547.2010. 00065.x.a.

Breen, G. 2000. Introductory Dictionary of Western Arrernte. Alice Springs, NT: IAD Press.

Curr, E. M. 1886-87. The Australian Race. 4 vols. Melbourne: J. Ferres.

Green, J. 2012. The Altyerre story: 'Suffering Badly by Translation'. TAJA 23(2): 158-78. doi.org/10.1111/j.1757-6547.2012.00179.x.

Hiatt, L. R. 1996. Arguments about Aborigines: Australia and the evolution of social anthropology. Cambridge: Cambridge University Press.

Hill, B. 2002. Broken Song: T. G. H. Strehlow and Aboriginal possession. Sydney: Knopf/Random House Australia. 
Howitt, A. W. 1904. The Native Tribes of South-East Australia. London: Macmillan \& Co.

Kempe, H. 1882. Plants indigenous about the River Finke, Central Australia. Transactions and Proceedings and Report of the Royal Society of South Australia 5: 19-24.

Kempe, H. 1883. Zur Sittenkunde der Centralaustralischen Schwarzen [About customs of Central Australian blacks]. Mitteilungen des Vereins für Erdkunde zu Halle [Journal of the Halle Geographical Society]: 52-6.

Kempe, H. 1891a. A grammar and vocabulary of the language spoken by the Aborigines of the MacDonnell Ranges. Transactions of the Royal Society of South Australia 14(1): 1-54.

Kempe, H. 1891b. Galtjintana-Pepa Kristianirberaka Mbontala. Hermannsburg in Hannover: Missionshandlung.

Kenny, A. 2013. The Aranda's Pepa: An introduction to Carl Strehlow's masterpiece Die Aranda- und Loritja-Stämme in Zentral-Australien (1907-1920). Canberra: ANU E Press.

Koch, H. forthcoming. The development of Arandic subsection names in time and space. In Skin, Kin and Clan: The dynamics of social categories in Indigenous Australia, (eds) P. McConvell, P. Kelly and S. Lacrampe. Canberra: ANU Press.

Kolig, E. 1992. Religious power and the all-father in the sky: Monotheism in Australian Aboriginal culture reconsidered. Anthropos 87: 9-31.

Krichauff, F. E. H. 1886. Customs, religious ceremonies, etc., of the 'Aldolinga' or 'Mbenderinga' tribe of Aborigines of the Krichauff Ranges, South Australia. Proceedings of the Royal Society of Australia, $S A$ (1886-87): 32-7, 77-80.

Moore, D. 2015. The Reformation, Lutheran tradition and missionary linguistics. Lutheran Theological Journal 49: 36-48.

Pink, O. 1936. The landowners in the northern division of the Aranda Tribe, Central Australia. Oceania 6(3): 275-305.

Ridley, W. 1861. Journal of a missionary tour among the Aborigines of the western interior of Queensland, in the year 1855. In Queensland, Australia, (ed.) J. D. Lang, Appendix I. London: Stanford. 
Róheim, G. 1971 [1945]. The Eternal Ones of the Dream: A psychoanalytic interpretation of Australian myth and ritual. New York: International Universities Press.

Scherer, P. A. 1963. Venture of Faith: An epic in Australian missionary history. Tanunda, SA: Auricht's Printing Office.

Scherer, P. A. 2004. Kempe, Friedrich Adolf Hermann (1844-1928). Australian Dictionary of Evangelical Biography. Sydney: Evangelical History Association of Australia. Available at: webjournals.ac.edu.au/ ojs/index.php/ADEB/article/view/1064/1061. Accessed 29 July 2015.

Schild, M. 2004. Heading for Hermannsburg: Notes on Carl Strehlow's early career path. Occasional Paper No. 3, (ed.) W. Veit, pp. 51-58. Strehlow Research Centre, Alice Springs, NT.

Schulze, L. 1891. The Aborigines of the upper and middle Finke River: Their habits and customs. Transactions and Proceedings of the Royal Society of South Australia 14(2): 210-46.

Spencer, W. B. and Gillen, F. J. 1899. The Native Tribes of Central Australia. London: Macmillan.

Spencer, W. B. and Gillen, F. J. 1904. The Northern Tribes of Central Australia. London: Macmillan.

Spencer, W. B. and Gillen, F. J. 1927. The Arunta. 2 vols. London: Macmillan \& Co.

Strehlow, C. 1907-1920. Die Aranda- und Loritja-Stämme in ZentralAustralien. 7 vols. Frankfurt am Main: Joseph Baer \& Co.

Strehlow, J. 2004. Reappraising Carl Strehlow: Through the SpencerStrehlow debate. Occasional Paper No. 3, (ed.) W. Veit, pp. 59-91. Strehlow Research Centre, Alice Springs, NT.

Strehlow, T. G. H. 1947. Aranda Traditions. Melbourne: Melbourne University Press.

Strehlow, T. G. H. 1971. Songs of Central Australia. Sydney: Angus \& Robertson. 
Strehlow, T. G. H. 1978 [1964]. Central Australian Religion: Monototemism in a polytotemic community. Adelaide: Australian Association for the Study of Religion.

Swain, T. 1985. Interpreting Aboriginal Religion: An historical account. Adelaide: Australian Association for the Study of Religion.

Wendt, R. 2001. Einleitung: Missionare als Reporter und Wissenschaftler in Übersee. In Sammeln, Vernetzen, Auswerten. Missionare und ihr Beitrag zum Wandel europäischer Weltsicht, (Hrsg.) R. Wendt, pp. 7-22. Tübingen: Gunter Narr Verlag. 
This text is taken from German Ethnography in Australia, edited by Nicolas Peterson and Anna Kenny, published 2017 by ANU Press, The Australian National University, Canberra, Australia.

dx.doi.org/10.22459/GEA.09.2017.07 